\title{
Successful implementation of information and communication technology integration in Malaysian public schools: an activity systems analysis approach
}

\begin{abstract}
This multiple-case study drew upon Engeström's (1987) activity theory (AT) to understand the conditions and explain the systematic contradictions that facilitate successful Information and Communication Technology (ICT) integration in schools. The data were collected through in-depth interviews and document analysis from one primary and one secondary public school in Malaysia. In-depth interviews were carried out with nine participants, including principals, ICT coordinators, and teachers. Findings revealed three conditions that led to successful ICT integration: 1) types of ICT tools in the school, 2) rules and regulations in the school that shape the ICT culture, and 3) division of labour within the school community. The findings indicate that school stakeholders must work together to resolve tensions introduced by systemic contradictions in different activity systems, which shape school ICT culture. The study aims to enrich the discourse on ICT integration by assisting school stakeholders to reflect on their own ICT integration strategies.
\end{abstract}

Keyword: ICT integration effectiveness; Evaluation utilization; Successful ICT integration; Activity theory; Activity systems analysis approach; Systemic contradictions 